\title{
Kombinasi Bubur Buah Nipah dengan Nanas serta Penambahan Gum Arab pada Mutu dan Karakteristik Sensori Fruit Leather
}

\author{
Effect of Nipa and Pineapple Fruit Pulp Combination with Arabic Gum on the Quality \\ and Sensory Characteristics of Fruit Leather \\ Dewi Fortuna Ayu*, Vonny Setiaries Johan, Tari Zulfalina \\ Program Studi Teknologi Hasil Pertanian, Fakultas Pertanian, Universitas Riau, \\ Kampus Bina Widya Km. 12,5, Pekanbaru 28293, Indonesia \\ *Penulis korepondensi: Dewi Fortuna Ayu, Email: Dewi.fortuna@lecturer.unri.ac.id
}

Tanggal submisi: 4 Desember 2018; Tanggal revisi: 12 April 2020; Tanggal penerimaan: 9 Juli 2020

\begin{abstract}
ABSTRAK
Tujuan penelitian ini untuk memperoleh perlakuan terbaik dari kombinasi bubur buah nipah dengan nanas serta penambahan gum arab pada mutu dan karakteristik sensori fruit leather. Penelitian eksperimen dilaksanakan secara acak lengkap faktorial dengan 3 ulangan. Perlakuan faktor pertama adalah perbandingan bubur buah nipah dengan nanas antara lain B1 (75\%:25\%), B2 (50\%:50\%), dan B3 (25\%:75\%). Faktor kedua adalah konsentrasi gum arab antara lain G1 (1\%), dan G2 (1.2\%). Analisis sidik ragam dan uji Duncan's New Multiple Range Test pada taraf 5\% digunakan untuk menganalisis data secara statistik. Hasil analisis memperlihatkan perbandingan bubur buah nipah dengan nanas mempengaruhi secara nyata kadar air, abu, serat kasar, gula total, total padatan terlarut, $\mathrm{pH}$, dan pengujian sensori terhadap warna, aroma, rasa, serta tekstur fruit leather. Konsentrasi penambahan gum arab mempengaruhi secara nyata kadar air, abu, serat, total padatan terlarut, $\mathrm{pH}$, dan pengujian sensori terhadap aroma fruit leather. Interaksi kedua faktor mempengaruhi secara nyata $\mathrm{pH}$ dan kadar serat fruit leather. Perlakuan terbaik penelitian ini adalah B3G2 (25\% bubur buah nipah:75\% bubur buah nanas pada konsentrasi gum arab 1,2\%) dengan kadar air 12,83\%, abu 0,79\%, serat kasar 2,05\%, gula total $21,21 \%$, total padatan terlarut $32,08{ }^{\circ}$ brix, dan $\mathrm{pH} 4,51$. Hasil pengujian deskriptif terhadap fruit leather menunjukkkan bahwa fruit leather berwarna kuning $(4,23)$, beraroma buah nanas $(3,93)$, rasa manis sedikit asam $(3,43)$, tekstur agak keras $(3,90)$, dan penilaian keseluruhan secara hedonik disukai panelis $(4,06)$.
\end{abstract}

Kata kunci: Gum arab; fruit leather; nipah; nanas

\begin{abstract}
This study aims to obtain the best treatment from combination of nipa and pineapple fruit pulp with arabic gum on the quality and sensory characteristics of fruit leather. The experimental method was a completely randomized design factorial with three repetitions. The first factor was the ratio of nipa and pineapple pulp namely B1 (75\%: $25 \%)$, B2 (50\%: $50 \%)$, and B3 (25\%: 75\%), while the second factor was arabic gum concentration namely G1 $(1 \%)$ and G2 (1.2\%). Analysis of variance and Duncan's New Multiple Range Test at 5\% level were used to analyze the data statistically. The analysis results showed that the ratio of nipa and pineapple pulp significantly
\end{abstract}


affected moisture, ash, fiber, and total sugar contents, as well as total dissolved solids, $\mathrm{pH}$, and sensory test of color, flavor, taste, and texture of the fruit leather. Furthermore, the addition of arabic gum concentration significantly affected moisture, ash, fiber content, total dissolved solids, $\mathrm{pH}$, and sensory test of fruit leather's flavor. Meanwhile, the interaction between these two factors significantly affected pH and fiber content of the fruit leather. The best treatment was B3G2 ( $25 \%$ nipa pulp: $75 \%$ pineapple pulp with $1.2 \%$ arabic gum concentration) with $12.83 \%$ moisture, $0.79 \%$ ash, $2.05 \%$ fiber, $21.21 \%$ total sugar content, $32.08^{\circ}$ brix total dissolved solids, and $4.51 \mathrm{pH}$. The descriptive test results showed that the fruit leather had yellow color (4.23), pineapple scented (3.93), sweet with a slightly sour taste (3.43), slightly chewy texture (3.90), and the hedonic overall assessment was favored by panelists (4.06).

Keywords: Arabic gum; fruit leather; nipa; pineapple

\section{PENDAHULUAN}

Indonesia sebagai negara tropis yang mempunyai areal luas hutan mangrove serta banyak ditumbuhi nipah (Nypa fruticans Wurmb.), menyebar di beberapa wilayah kawasan Sumatera, Sulawesi Kalimantan, Papua, dan Maluku. Walaupun hutan mangrove memiliki areal yang luas, buah nipah termasuk potensi sumber daya alam yang sering terabaikan dan kurang mendapat perhatian, terutama di wilayah pesisir Provinsi Riau. Di Provinsi Riau, potensi nipah tersebar hampir di seluruh Kabupaten. Kabupaten Bengkalis termasuk satu diantara daerah lain yang ditumbuhi tanaman nipah \pm 100 ha (Astuti dkk., 2016).

Buah nipah termasuk bahan pangan yang mempunyai kandungan gizi baik. Buah nipah yang sering dikonsumsi masyarakat adalah buah nipah agak tua, karena buah nipah agak tua memiliki tekstur yang kenyal, mudah dikonsumsi, serta memberikan manfaat bagi kesehatan, diantaranya mampu menurunkan kolestrol (Dalming dkk., 2018). Menururt Ristiyana (2012), buah nipah agak tua yang mengandung 4,49\% kadar lemak, $3,74 \%$ protein, serta $1,83 \%$ serat, berpotensi diolah menjadi koktail. Namun penelitian Prasad dkk. (2013) menunjukkan bahwa ekstrak endosperm buah nipa yang belum matang memiliki kapasitas antioksidan lebih tingi dibandingkan buah matang yang ditunjukkan dengan kandungan total fenolilk dan flavonoid yang tinggi.

Buah nipah termasuk buah musiman berbuah selama setahun dua kali yaitu di bulan Maret sampai April serta Agustus sampai September. Buah nipah dimanfaatkan hingga saat ini terbatas untuk konsumsi bagi masyarakat sekitar (Ristiyana, 2012). Produksi dan pemamfaatan bahan baku yang terbatas menyebabkan diperlukannya teknologi pengolahan yang tepat sehingga buah nipah agak tua dapat dinikmati setiap saat serta memberikan nilai ekonomi tinggi bagi masyarakat. Salah satu produk olahan yang setiap saat dapat dinikmati berupa fruit leather.

Fruit leather adalah makanan dari daging buah yang sudah dihancurkan, kemudian gula, pektin, asam, sirup glukosa, pewarna, dan kalium metabisulphiteditambahkan untuk selanjutnya dikeringkan menggunakan berbagai sistem pengeringan termasuk gabungan pengering konvektif dan far-infra red, udara panas, microwave, dan matahari. Umumnya fruit leather dikeringkan selama 24 jam pada suhu 30 sampai $80{ }^{\circ} \mathrm{C}$ agar memperoleh kadar air akhir $12-2 \%$ (Diamante dkk., 2014). Buah nipah dapat diolah menjadi fruit leather karena buah nipah agak tua mengandung serat yang tinggi, namun pemanfaatan buah nipah menjadi fruit leather masih memiliki kekurangan yaitu tidak memiliki warna dan rasa, sehingga buah nipah harus dikombinasikan dengan buah lainnya seperti nanas.

Tanaman nanas (Ananas comosus L.) memiliki prospek cerah untuk dikembangkan, menurut Badan Pusat Statistik 2016, di Riau produksi buah nanas cukup tinggi yaitu 74.389 ton (BPS, 2016). Buah nanas mempunyai warna kuning, aroma khas, dan rasa asam yang terbentuk selama proses pematangan dan pemasakan. Selama proses pematangan klorofil mengalami degradasi menjadi kuning begitu juga daging buah yang berubah dari putih menjadi kuning. Lebih dari 200 senyawa aroma dalam buah nanas telah teridentifikasi termasuk ester, lakton, aldehida, keton, alkohol, asam karbonil, hidrokarbon, fenol dan senyawa sulfur. Sedangkan asam organik non-volatil utama dalam buah nanas adalah asam malat dan asan sitrat, dengan rasio 1 :2-3 (Hassan dkk., 2011). Karakteristik warna, rasa dan aroma khas buah nanas ini memungkinkan buah nanas dapat dimanfaatkan sebagai bahan tambahan guna memperbaiki produk. Buah nanas banyak diminati masyarakat, terbukti dengan banyaknya produk olahan dari nanas yang dijumpai di pasaran, diantaranya dodol, keripik, selai, serta jeli nanas.

Karakteristik buah nipah dan buah nanas yang berbeda menyebabkan kombinasi antara buah nipah dan buah nanas dalam pemanfaatan fruit leather memungkinkan tekstur yang kurang homogen dan kurang elastis. Salah satu upaya guna memperbaiki kekurangan tersebut adalah dengan penambahan gum arab. Gum arab secara komprehensif digunakan sebagai 
stabilizer, pengental, emulsifier, dan sebagian kecil pada industri tekstil, gerabah, litografi, kosmetik dan farmasi. Dalam industri makanan, gum arab digunakan dalam industri permen, roti, susu, minuman, dan sebagai agen mikroenkapsulasi (Montenegro dkk., 2012). Penelitian penggunaan gum arab pada pembuatan fruit leather dan kombinasi beberapa buah telah dilakukan, diantaranya penelitian Lubis (2014) yang meneliti kombinasi buah nanas dengan pepaya pada fruit leather dengan hasil terbaik sebesar 50\%:50\% dengan penambahan 1,2\% gum arab. Fruit leather terbaik dari kombinasi buah sirsak dengan papaya telah diperoleh Harahap dkk. (2015) pada rasio 30\%:70\% dengan penambahan gum arab terbaik sebesar $1 \%$. Berdasarkan uraian di atas penulis melakukan penelitian kombinasi buah nipah dengan buah nanas serta penambahan gum arab yang bertujuan mendapatkan perlakuan terbaik terhadap mutu serta karakteristik sensori fruit leather.

\section{METODE PENELITIAN}

\section{Bahan Penelitian}

Buah nipah diperoleh dari Desa Bantan Tua, Kecamatan Bantan, Kabupaten Bengkalis dan buah nanas madu varietas cayene dari Desa Mamugo, Kecamatan Tanah Putih, Kabupaten Rokan Hilir, Provinsi Riau, serta gum arab (type 4687, PT. Brataco, Cikarang, Bekasi) digunakan sebagai bahan utama fruit leather. Bahan-bahan lain yang digunakan antara lain asam sitrat dan gula pasir. Bahan untuk analisis kimia antara lain alkohol, larutan luff schoorl, amilum, indikator phenolphthalein (pp), $\mathrm{Pb}$ asetat, $\mathrm{H}_{2} \mathrm{SO}_{4}, \mathrm{NaOH} \mathrm{K} \mathrm{SO}_{4}$, $\left(\mathrm{NH}_{4}\right)_{2} \mathrm{HPO}_{4}, \mathrm{HCl}$, $\mathrm{KI}$, dan Na-thiosulfat (Merck, 99\%).

\section{Pelaksanaan Penelitian}

Rancangan acak lengkap (RAL) faktorial dengan 3 ulangan digunakan pada eksperimen penelitian ini. Faktor pertama perbandingan buah nipah dengan buah nanas (B) dengan taraf B1 (75\% bubur buah nipah dan $25 \%$ bubur buah nanas), B2 (50\% bubur buah nipah dan $50 \%$ bubur buah nanas), dan B3 (25\% bubur buah nipah dan $75 \%$ bubur buah nanas). Faktor kedua perbandingan konsentrasi gum arab (G) dengan taraf G1 (1\% Gum arab) dan G2 (1,2\% Gum arab).

\section{Pembuatan bubur buah nipah}

Buah nipah yang dipilih adalah buah nipah agak tua, dengan karakteristik bonggol berwarna coklat kemerahan, tekstur buah sedikit lebih keras tetapi masih dapat dimakan. Buah nipah dibelah diambil daging buahnya, dicuci sampai bersih dengan air yang mengalir, kemudian dipotong-potong menjadi berukuran kecil agar memudahkan dalam penghancuran daging buah. Daging buah nipah yang sudah dipotong lalu dihancurkan menggunakan blender dengan penambahan air setengah dari berat bahan hingga memperoleh tekstur bubur buah lembut.

\section{Pembuatan bubur buah nanas}

Buah nanas yang cukup matang dipilih untuk diolah, ditandai dengan ukuran buah sedang dengan kulit buah berwana kuning. Buah nanas dikupas kulitnya, dibuang mata dan bonggolnya, kemudian daging buah dicuci sampai bersih dengan menggunakan air mengalir kemudian dipotong-potong hingga berukuran kecil agar memudahkan dalam penghancuran daging buah. Potongan-potongan kecil buah nanas kemudian dihancurkan menggunakan blender.

\section{Pembuatan fruit leather}

Modifikasi penelitian Lubis (2014) pada penggunaan bahan baku digunakan sebagai acuan dalam pembuatan fruit leather. Hancuraan bubur buah ditimbang sesuai perlakuan, ditambahkan gum arab, selanjutnya ditambahkan $20 \%$ gula dan $0,2 \%$ asam sitrat pada masing-masing perlakuan. Sampel dipanaskan selama 2 menit di suhu $70{ }^{\circ} \mathrm{C}$ agar menginaktivasi enzim yang terdapat pada buah. Adonan telah dipanaskan selanjutnya dituang pada ketebalan $2 \mathrm{~mm}$ ke cetakan yang sudah dilapisi aluminum foil menggunakan sendok, setelah itu dikeringkan selama 16 jam di suhu $50{ }^{\circ} \mathrm{C}$ dalam oven. Adonan kering selanjutnya dipotong berukuran $3,5 \times 3,5 \mathrm{~cm}$ lalu digulung. Formulasi adonan fruit leather tertera dalam Tabel 1 dan 2 .

\section{Pengamatan}

Pengamatan terhadap kadar air, abu, serat kasar, gula total, $\mathrm{pH}$, dan total padatan terlarut fruit leather mengacu pada BSN 3746 (2008). Penilaian sensori, antara lain uji deskriptif dan hedonik mengacu Setyaningsih dkk. (2010).

Total padatan terlarut diukur menggunakan prisma refraktometer. Akuades sebanyak satu tetes diteteskan ke prisma reftraktometer guna menentukan titik nol atau koreksi. Larutan sampel kemudian diteteskan sebanyak 2-3 tetes ke atas prisma, selanjutnya dibuat menyebar pada permukaan prisma hingga batas gelap serta terang menjadi tepat dan jelas terletak pada tengah lensa. Nilai total satu tetes padatan terlarut dapat langsung dibaca pada refraktometer.

Penilaian deskriptif dilakukan guna mengetahui penilaian panelis terhadap warna, aroma, rasa, serta 
Tabel 1. Formulasi adonan fruit leather (penambahan gum arab 1\%)

\begin{tabular}{lrrr}
\hline \multirow{2}{*}{ Bahan (g) } & \multicolumn{3}{c}{ Perlakuan } \\
\cline { 2 - 4 } & $\mathrm{B}_{1} \mathrm{G}_{1}$ & $\mathrm{~B}_{2} \mathrm{G}_{1}$ & $\mathrm{~B}_{3} \mathrm{G}_{1}$ \\
\hline Bubur buah nipah & 59,10 & 39,40 & 19,70 \\
Bubur buah nanas & 19,70 & 39,40 & 59,10 \\
Gula pasir & 20,00 & 20,00 & 20,00 \\
Gum arab & 1,00 & 1,00 & 1,00 \\
Asam sitrat & 0,20 & 0,20 & 0,20 \\
Jumlah & 100,00 & 100,00 & 100,00 \\
\hline
\end{tabular}

Tabel 2. Formulasi adonan fruit leather (penambahan gum arab $1,2 \%$ )

\begin{tabular}{lrrr}
\hline \multirow{2}{*}{ Bahan (g) } & \multicolumn{3}{c}{ Perlakuan } \\
\cline { 2 - 4 } & $\mathrm{B}_{1} \mathrm{G}_{2}$ & $\mathrm{~B}_{2} \mathrm{G}_{2}$ & \multicolumn{1}{c}{$\mathrm{B}_{3} \mathrm{G}_{2}$} \\
\hline Bubur buah nipah & 59,10 & 39,40 & 19,70 \\
Bubur buah nanas & 19,70 & 39,40 & 59,10 \\
Gula pasir & 20,00 & 20,00 & 20,00 \\
Gum arab & 1,20 & 1,20 & 1,20 \\
Asam sitrat & 0,20 & 0,20 & 0,20 \\
Jumlah & 100,20 & 100,20 & 100,20 \\
\hline
\end{tabular}

Tabel 3. Hasil sidik ragam karateristik kimia fruit leather

\begin{tabular}{|c|c|c|c|c|c|c|}
\hline \multirow{2}{*}{$\begin{array}{c}\text { Parameter } \\
\text { karakteristik kimia }\end{array}$} & \multicolumn{6}{|c|}{ Perlakuan } \\
\hline & B1G1 & B2G1 & B3G1 & B1G2 & B2G2 & B3G2 \\
\hline $\begin{array}{l}\text { Kadar air } \\
(\%)\end{array}$ & $14,34^{\mathrm{a}} \pm 0,244$ & $13,14^{b} \pm 0,020$ & $12,42^{\mathrm{d}} \pm 0,341$ & $14,84^{b} \pm 0,205$ & $13,59^{c} \pm 0,118$ & $12,83^{e} \pm 0,104$ \\
\hline $\begin{array}{l}\text { Kadar abu } \\
(\%)\end{array}$ & $0,88^{b} \pm 0,030$ & $0,79^{\mathrm{a}} \pm 0,025$ & $0,78^{a} \pm 0,005$ & $0,92^{\mathrm{c}} \pm 0,030$ & $0,81^{\mathrm{a}} \pm 0,015$ & $0,79^{a} \pm 0,010$ \\
\hline $\begin{array}{c}\text { Kadar serat kasar } \\
(\%)\end{array}$ & $3,22^{c} \pm 0,060$ & $2,17^{a} \pm 0,050$ & $1,97^{\mathrm{a}} \pm 0,050$ & $3,89^{d} \pm 0,070$ & $2,61^{\mathrm{b}} \pm 0,246$ & $2,05^{\mathrm{a}} \pm 0,051$ \\
\hline $\begin{array}{c}\text { Kadar gulaTotal } \\
(\%)\end{array}$ & $24,15^{\mathrm{bc}} \pm 0,066$ & $22,94^{b} \pm 0,498$ & $20,80^{\mathrm{a}} \pm 0,787$ & $24,20^{\complement} \pm 0,050$ & $23,00^{\mathrm{bc}} \pm 0,566$ & $21,21^{\mathrm{a}} \pm 0,780$ \\
\hline $\begin{array}{l}\text { Total padatan terlarut } \\
\text { ('brix) }\end{array}$ & $35,00^{\mathrm{b}} \pm 0,121$ & $32,88^{\mathrm{bc}} \pm 0,386$ & $31,65^{a} \pm 0,145$ & $35,90^{\complement} \pm 0,058$ & $33,54^{b c} \pm 0,070$ & $32,08^{\mathrm{a}} \pm 0,045$ \\
\hline Nilai pH & $4,62^{d} \pm 0,005$ & $4,56^{\mathrm{b}} \pm 0,010$ & $4,50^{\mathrm{a}} \pm 0,005$ & $4,59^{c} \pm 0,010$ & $4,56^{\mathrm{b}} \pm 0,005$ & $4,51^{\mathrm{a}} \pm 0,000$ \\
\hline
\end{tabular}

Ket: Menurut uji DNMRT pada taraf 5\%, huruf kecil yang sama pada angka dalam kolom memperlihatkan berbeda tidak nyata.

tekstur sampel fruit leather, sedangkan penilaian hedonik bertujuan menentukan kesukaan keseluruhan panelis terhadap fruit leather. Sampel fruit leather disajikan dengan cara digulung sebanyak 1 buah untuk setiap perlakuan pada wadah yang bersih serta diberi kode berupa angka acak. Setelah menguji sampel, air putih diberikan ke panelis guna menetralkan lidah sebelum mencicipi sampel berikutnya. Masing-masing panelis diminta memberikan penilaian pada setiap sampel dengan mengisi hasil penilaiannya di lembar penilaian yang disajikan.

\section{Analisis Data}

Microsoft Excel 2003 digunakan untuk mengolah data yang diperoleh, secara statistik menggunakan analisis sidik ragam. Selanjutnya Uji Duncan's New
Multiple Range Test (DNMRT) pada taraf $5 \%$ dilakukan jika $F_{\text {hitung }} \geq F_{\text {tabe. }}$

\section{HASIL DAN PEMBAHASAN}

Hasil sidik ragam karakteristik kimia fruit leather berupa kadar air, abu, serat kasar, gula total, total padatan terlarut, serta $\mathrm{pH}$ tersaji dalam Tabel 3.

\section{Kadar Air}

Perbandingan bubur buah nipah dengan nanas terhadap kadar air fruit leather memberikan pengaruh nyata $(p<0,05)$, hal ini ditunjukkan dalam hasil sidik ragam (Tabel 3). Fruit leather memiliki kadar air yang semakin meningkat dengan semakin banyaknya bubur 
buah nipah atau semakin sedikit bubur buah nanas. Hal ini berkaitan dengan perbedaan kandungan air pada masing-masing bahan baku yang digunakan. Buah nipah memiliki kadar air lebih tinggi $(91,80 \%)$, daripada kadar air buah nanas (84,76\%). Tingginya kadar air bubur buah nipah dikarenakan adanya penambahan air saat pembuatan bubur buah nipah yaitu $1: 1 / 2$ dari berat bahan, sedangkan pada pembuatan bubur buah nanas tidak dilakukan penambahan air.

Kadar air fruit leather juga dipengaruhi kadar serat khususnya serat larut air berupa pektin dalam bahan. Berdasarkan analisis bahan baku, serat dalam bubur buah nipah sebesar 2,09\% sedangkan serat bubur buah nanas $0,40 \%$. Fakta ini sejalan dengan Darojat (2010) yang menyebutkan banyaknya kadar serat mampu mempengaruhi kadar air pada fruit leather, berkaitan dengan kemampuan serat yang menyerap serta mempertahankan air. Molekul polimer serat pangan larut air berukuran besar dengan struktur yang kompleks, kapasitas mengikat air yang besar, serta memiliki banyak gugus hidroksil bebas. Kondisi lingkungan seperti suhu, $\mathrm{pH}$, kekuatan ionik, konstanta dielektrik larutan dan sifat ionik dapat mempengaruhi karakteristik hidrasi serat yang mengandung polielektrolit (grup bermuatan seperti karboksil dalam serat kaya pektin, grup karboksil dan sulfat dalam serat dari alga) (Dhingra dkk., 2012).

Kadar air fruit leather memperlihatkan penambahan gum arab memberikan pengaruh nyata $(p<0,05)$, akan tetapi interaksi perbandingan bubur buah nipah dengan nanas serta penambahan gum arab menunjukkan pengaruh tidak nyata $(p>0,05)$ (Tabel 3). Gum arab mampu mengikat air sangat baik dalam bahan dan berfungsi sebagai penstabil, sehingga untuk produk pengguna gum arab sebagai penstabil dapat memiliki kadar air cukup tinggi. Penelitian ini sejalan penelitian Lubis (2014), dimana semakin tinggi penambahan konsentrasi gum arab menyebabkan fruit leather buah nanas dengan pepaya memiliki kadar air yang semakin tinggi.

\section{Kadar Abu}

Perbandingan bubur buah nipah dengan nanas terhadap kadar abu fruit leather memberikan pengaruh nyata $(p<0,05)$, hal ini ditunjukkan dalam hasil sidik ragam (Tabel 3). Hal ini terkait dengan perbedaan kadar abu bahan baku fruit leather. Berdasarkan analisis, bubur buah nipah memiliki kadar abu sebesar $1,59 \%$, lebih tinggi dibandingkan kadar abu bubur buah nanas yaitu $0,55 \%$.

Kadar abu berhubungan dengan kadar mineral yang terdapat dalam bahan pangan. Menurut Rabbah dan Abdalla (2012), kandungan garam mineral dalam gum arab antara lain kalsium 1,117 $\mathrm{mg}$, pottasium $310 \mathrm{mg}$, magnesium $292 \mathrm{mg}$, dan sodium $14 \mathrm{mg}$, sedangkan menurut Mahmud dkk. (2018), kandungan mineral buah $100 \mathrm{~g}$ nanas segar yaitu $0,9 \mathrm{mg}$ besi, kalsium $22 \mathrm{mg}$, fosfor $14 \mathrm{mg}$, natrium $18 \mathrm{mg}$, kalium $111,0 \mathrm{mg}$, dan seng $0.1 \mathrm{mg}$.

Kadar abu fruit leather memperlihatkan penambahan gum arab memberikan pengaruh nyata $(p<0,05)$, akan tetapi interaksi perbandingan bubur buah nipah dengan nanas serta penambahan gum arab menunjukkan pengaruh tidak nyata $(p>0,05)$ (Tabel 3). Kandungan garam mineral dalam gum arab yang tinggi menyebabkan penambahan gum arab semakin banyak maka kadar abu fruit leather juga semakin tinggi. Fenomena ini sejalan penelitian Prasetyowati dkk. (2014), fruit leather memiliki kadar abu yang dipengaruhi oleh penggunaan gum arab, dimana fruit leather nanas dengan wortel memiliki kadar abu yang meningkat seiring peningkatan penambahan gum arab 0,3-0,9\%, kadar abu yang diperoleh berkisar 2,23-2,43\%.

\section{Kadar Serat Kasar}

Perbandingan bubur buah nipah dengan nanas terhadap kadar serat kasar fruit leather memberikan pengaruh nyata $(p<0,05)$, hal ini ditunjukkan dalam hasil sidik ragam (Tabel 3 ). Fruit leather memiliki kadar serat kasar yang semakin meningkat dengan semakin banyaknya bubur buah nipah atau semakin sedikit bubur buah nanas dalam fruit leather, bubur buah nipah memiliki kadar serat lebih tinggi $(2,09 \%)$ dibandingkan bubur buah nanas $(0,40 \%)$.

Kadar serat kasar fruit leather menunjukkan penambahan konsentrasi gum arab memberikan pengaruh nyata $(p<0,05)$ (Tabel 3$)$. Konsentrasi penggunaan gum arab yang semakin tinggi, maka fruit leather memiliki kadar serat kasar semakin tinggi. Gum arab termasuk serat pangan larut air dengan kandungan $45 \%$ galaktosa, $24 \%$ arabinosa, $16 \%$ asam galakturonat, dan $13 \%$ rhamnosa (Prasetyowati dkk., 2014), kandungan gum arab ini dapat memperkaya kadar serat kasar dalam fruit leather.

Interaksi perbandingan bubur buah nipah dengan nanas serta konsentrasi gum arab terhadap kadar serat kasar fruit leather memperlihatkan pengaruh nyata $(p<0,05)$, hal ini ditunjukkan dalam hasil sidik ragam (Tabel 3). Penambahan bubur buah nipah serta gum arab yang semakin banyak maka kadar serat kasar fruit leather menjadi semakin tinggi, berkaitan dengan kadar serat pada buah nipah yang lebih tinggi dibandingkan buah nanas, begitu juga gum arab yang mengandung kadar serat yang tinggi berupa 
serat pangan larut air sebesar $86,6 \mathrm{mg}$ dengan total karbohidrat sebesar 86,6 mg (Rabah dan Abdalla, 2012). Gum Arab merupakan esksudat tinggi serat dari tanaman Acacia Senegal dan Acacia Seya yang mengandung kurang dari $85 \%$ larut serat makanan (basis kering) (Sulieman, 2018).

\section{Kadar Gula Total}

Perbandingan bubur buah nipah dengan nanas terhadap kadar gula total fruit leather memberikan pengaruh nyata $(p<0,05)$, hal ini ditunjukkan dalam hasil sidik ragam (Tabel 3). Fruit leather memiliki kadar gula total yang semakin meningkat dengan semakin banyaknya bubur buah nipah atau semakin sedikit bubur buah nanas. Kandungan gula masing-masing bahan baku menyebabkan perbedaan kadar gula total fruit letaher, dimana kadar gula total bubur buah nipah $4,72 \%$ sedangkan bubur buah nanas $2,78 \%$.

Kadar gula total fruit leather menunjukkan penambahan konsentrasi gum arab memberikan pengaruh tidak nyata $(p>0,05)$ (Tabel 3$)$. Perbedaan penambahan gum arab yang rendah (1-1,2\%) pada penelitian ini tidak mampu memberikan pengaruh nyata pada kadar gula total dalam fruit leather.

Kadar gula total dalam fruit leather lebih dipengaruhi oleh penambahan gula pasir sebanyak $20 \mathrm{~g}$ yang dilakukan selama pembuatan fruit leather. Menurut Fauziah dkk. (2015) penambahan gula dalam fruit leather pisang tanduk bertujuan memperbaiki cita rasa bahan makanan agar meningkatkan kelezatan dengan rasa manis yang ditimbulkan. Mahmud dkk. (2018) mengatakan bahwa kandungan karbohidrat dalam $100 \mathrm{~g}$ gula putih sebesar 94\%. Akan tetapi, dalam penelitian ini tidak dilakukan perbedaan penambahan gula pasir selama proses pembuatan fruit leather.

\section{Total Padatan Terlarut}

Perbandingan bubur buah nipah dengan nanas terhadap total padatan terlarut fruit leather memberikan pengaruh nyata $(p<0,05)$, hal ini ditunjukkan dalam hasil sidik ragam (Tabel 3 ). Total padatan terlarut mengalami peningkatan dengan bubur buah nipah semakin banyak atau bubur buah nanas semakin sedikit. Hasil analisis bahan baku menunjukkan bahwa bubur buah nipah memiliki total padatan terlarut sebesar 10,45 ${ }^{\circ}$ brix, lebih tinggi dibandingkan bubur buah nanas yaitu $5,35^{\circ}$ brix.

Total padatan terlarut fruit leather menunjukkan penambahan gum arab memberikan pengaruh nyata $(p<0,05)$ (Tabel 3). Gum arab memiliki kemampuan mengikat air sekaligus senyawa-senyawa terlarut air sehingga mengakibatkan meningkatnya total padatan terlarut dalam fruit leather. Hasil diperoleh ini sejalan dengan Sulastri (2008), yang menyebutkan jika penambahan konsentrasi gum arab semakin tinggi, maka total padatan terlarut suatu produk akan semakin meningkat.

Total padatan terlarut dalam fruit leather berbanding lurus kadar gula dalam suatu bahan. Kadar gula total fruit leather berkisar antara 21,21-24,20\%, mengindikasikan kadar gula total yang semakin tinggi maka total padatan terlarut dalam fruit leather juga semakin tinggi. Buckle dkk. (2013) menyebutkan kandungan total padatan terlarut terdiri dari gula reduksi, gula non reduksi, asam organik, serta protein. Gula merupakan komponen penyusun dari total padatan terlarut, sehingga kadar gula total fruit leather semakin tinggi maka total padatan terlarut dalam fruit leather juga semakin tinggi.

\section{Nilai pH}

Perbandingan bubur buah nipah dengan nanas terhadap nilai $\mathrm{pH}$ fruit leather memberikan pengaruh nyata $(p<0,05)$, hal ini ditunjukkan dalam hasil sidik ragam (Tabel 3 ). Bubur buah nipah yang semakin banyak atau bubur buah nanas yang semakin sedikit maka nilai $\mathrm{pH}$ fruit leather semakin meningkat. Perbedaan nilai $\mathrm{pH}$ yang nyata tersebut dipengaruhi oleh derajat keasaman (nilai $\mathrm{pH}$ ) bahan baku yang digunakan. Berdasarkan hasil analisis, nilai pH bubur buah nipah 5,9 sedangkan bubur buah nanas 3,8 .

Nilai $\mathrm{pH}$ fruit leather memperlihatkan penambahan gum arab memberikan pengaruh berbeda nyata $(p<0,05)$ (Tabel 3). Penambahan yang semakin tinggi pada konsentrasi gum arab menyebabkan semakin rendah nilai $\mathrm{pH}$ fruit leather. Gum arab memiliki fungsi sebagai penstabil sehingga adanya gum arab akan mengikat air beserta asam-asam organik yang larut air ketika proses pengeringan, sehingga semakin banyak gum arab yang ditambahkan akan mempertahankan asam-asam organik pada fruit leather yang ditunjukkan dengan penurunan nilai pH fruit leather (Lubis, 2014).

Interaksi perbandingan bubur buah nipah dengan nanas serta penambahan gum arab terhadap nilai $\mathrm{pH}$ fruit leather memperlihatkan pengaruh nyata $(p>0,05)$ (Tabel 3). Penambahan bubur buah nanas serta gum arab yang semakin banyak maka nilai $\mathrm{pH}$ semakin rendah. Hal ini disebabkan nilai $\mathrm{pH}$ buah nanas 3,8 , buah nipah 5,9 serta gum arab berkisar 3,9-4,9. Selain itu, gum arab bersifat mengikat air sekaligus asam-asam organik yang terlarut dalam air, sehingga jika asam organik dalam air yang diikat oleh gum arab semakin banyak, maka nilai $\mathrm{pH}$ fruit leather semakin rendah. 
Tabel 4. Hasil sidik ragam penilaian sensori fruit leather

\begin{tabular}{lllllll}
\hline \multirow{2}{*}{ Parameter uji sensori } & \multicolumn{7}{c}{ Perlakuan } \\
\cline { 2 - 7 } & B1G1 & B2G1 & B3G1 & B1G2 & B2G2 & B3G2 \\
\hline Warna & $1,76^{\mathrm{a}}$ & $3,43^{\mathrm{b}}$ & $4,03^{\mathrm{c}}$ & $1,86^{\mathrm{a}}$ & $3,63^{\mathrm{b}}$ & $4,23^{\mathrm{c}}$ \\
Aroma & $2,13^{\mathrm{a}}$ & $2,93^{\mathrm{a}}$ & $3,80^{\mathrm{c}}$ & $3,33^{\mathrm{b}}$ & $3,20^{\mathrm{b}}$ & $3,93^{\mathrm{c}}$ \\
Rasa & $2,36^{\mathrm{a}}$ & $2,50^{\mathrm{a}}$ & $3,33^{\mathrm{b}}$ & $2,40^{\mathrm{a}}$ & $2,56^{\mathrm{a}}$ & $3,43^{\mathrm{b}}$ \\
Tekstur & $2,80^{\mathrm{a}}$ & $3,63^{\mathrm{a}}$ & $3,76^{\mathrm{b}}$ & $2,93^{\mathrm{a}}$ & $3,70^{\mathrm{b}}$ & $3,90^{\mathrm{b}}$ \\
Keseluruhan & $3,03^{\mathrm{a}}$ & $3,43^{\mathrm{b}}$ & $3,97^{\mathrm{c}}$ & $3,28^{\mathrm{b}}$ & $3,76^{\mathrm{c}}$ & $4,06^{\mathrm{d}}$ \\
\hline
\end{tabular}

Ket: Menurut uji DNMRT pada taraf 5\%, huruf kecil yang sama pada angka dalam kolom memperlihatkan berbeda tidak nyata.

Skor deskriptif:

-Warna, $\quad 1=$ Putih; $2=$ Sedikit putih; $3=$ Putih kekuningan; $4=$ Kuning; $5=$ Sangat kuning

-Aroma, $\quad 1$ = Sangat beraroma buah nipah; 2= Beraroma buah nipah; 3 =Agak beraroma buah nipah dan buah nanas; $4=$ Beraroma buah nanas, $5=$ Sangat beraroma buah nanas

-Rasa, $\quad 1=$ Sangat manis; $2=$ Manis; 3= Manis sedikit asam; 4= Agak asam; $5=$ Sangat asam

-Tekstur, $\quad 1$ = Sangat kenyal; $2=$ Kenyal; $3=$ Agak kenyal; 4=Agak keras; $5=$ Sangat keras

Skor hedonik:

$1=$ Sangat tidak suka; $2=$ Tidak suka; $3=$ Agak suka; $4=$ Suka; $5=$ Sangat suka

Kondisi $\mathrm{pH}$ rendah merupakan faktor penting dalam pembentukan struktur gel fruit leather. Menurut Nurlaely (2002), pektin, gula, serta asam merupakan komponen yang berperan dalam pembentukan gel. Pektin yang bersifat larut pada air panas, sehingga akan terbentuk pasta dalam larutan koloidal. Jika ditambah gula pada suasana asam dalam larutan pektin, maka gel akan terbentuk, seperti halnya gel fruit leather, selai, maupun jeli buah.

\section{Penilaian Sensori}

Hasil sidik ragam penilaian sensori terhadap warna, aroma, rasa, testur serta penilaian keseluruhan fruit leather tersaji dalam Tabel 4.

\section{Warna}

Perbandingan bubur buah nipah dengan nanas terhadap warna fruit leather memberikan pengaruh nyata $(p<0,05)$, hal ini ditunjukkan dalam hasil sidik ragam (Tabel 4). Bubur buah nipah yang semakin banyak cenderung memberikan warna fruit leather yang semakin putih, sedangkan bubur buah nanas yang semakin banyak mengakibatkan warna fruit leather yang semakin kuning. Hal ini dikarenakan kandungan pigmen karotenoid dalam nanas yang berwarna kuning, merah, serta merah orange (Winarno, 2008)

Warna fruit leather memperlihatkan penambahan konsentrasi gum arab memiliki pengaruh tidak nyata $(p>0,05)($ Tabel 4). Gum arab tidak memiliki warna sehingga penambahan gum arab 1-1,2\% tidak menyebabkan perbedaan warna yang nyata pada fruit leather.

\section{Aroma}

Perbandingan bubur buah nipah dengan nanas terhadap aroma fruit leather memberikan pengaruh nyata $(p<0,05)$, hal ini ditunjukkan dalam hasil sidik ragam (Tabel 4). Bubur buah nipah yang semakin sedikit atau semakin banyak bubur buah nanas pada setiap perlakuan menyebabkan semakin kuat aroma buah nanas pada fruit leather. Buah nanas mempunyai aroma lebih dominan dibandingkan buah nipah karena adanya senyawa-senyawa asam organik pada buah nanas. Asam organik non-volatil utama dalam buah nanas adalah asam malat dan asan sitrat, dengan rasio 1 :2-3 (Hassan dkk., 2011). Asam-asam tersebut memberikan aroma khas buah nanas.

Aroma fruit leather memperlihatkan penambahan gum arab memberikan pengaruh nyata $(p<0,05)($ Tabel 4). Gum arab dapat berperan sebagai pengikat aroma sehingga mampu mempertahankan aroma bahan selama proses pengeringan. Hal ini berkaitan dengan kemampuan gum arab melapisi partikel aroma sehingga mampu melindungi aroma terhadap oksidasi, evaporasi, serta absorpsi air dari udara (Suleiman, 2018).

Berdasarkan Winarno (2008), aroma termasuk satu diantara faktor penentu penerimaan konsumen terhadap makanan. Aroma fruit leather ini telah sesuai dengan syarat mutu selai buah (SNI 3746 : 2008), 
beraroma normal. Aroma normal pada fruit leather ini diartikan sebagai aroma khas bahan baku yaitu aroma buah nipah hingga nanas.

\section{Rasa}

Perbandingan bubur buah nipah dengan nanas terhadap rasa fruit leather memberikan pengaruh nyata $(p<0,05)$, hal ini ditunjukkan dalam hasil sidik ragam (Tabel 4). Bubur buah nipah yang semakin banyak maka semakin manis rasa fruit leather, sebaliknya bubur buah nanas yang semakin banyak maka cenderung manis sedikit asam rasa fruit leather, hal ini berkaitan dengan kandungan asam malat serta sitrat dalam buah nanas (Hassan dkk., 2011).

Rasa asam fruit leather juga dipengaruhi oleh nilai $\mathrm{pH}$. Nilai $\mathrm{pH}$ fruit leather berkisar 4,50-4,62. Nilai $\mathrm{pH}$ perlakuan B1G1 yaitu 4,62 menghasilkan fruit leather rasa manis, sedangkan perlakuan B1G3 memiliki nilai $\mathrm{pH} 4,50$ berasa manis sedikit asam. Hal ini berkaitan dengan nilai $\mathrm{pH}$ masing-masing bahan baku, bubur buah nipah memiliki pH sebesar 5,9 lebih tinggi daripada bubur buah nanas sebesar 3,8.

Rasa fruit leather memperlihatkan penambahan gum arab memberikan pengaruh berbeda tidak nyata $(p>0,05)$ (Tabel 4). Hal ini terkait dengan karakteristik gum arab yang tidak memiliki rasa. Menurut Yebeyen dkk. (2009), gum arab berwarna pucat hingga orang coklat, berbentuk solid dan dapat pecah, serta tidak memiliki rasa sehingga dapat digunakan sebagai bahan tambahan pangan tanpa memberikan gangguan karakteristik sensori pada produk pangan.

Rasa manis fruit leather sejalan dengan kadar gula total buah nipah dan buah nanas. Kadar gula total perlakuan B1G1 yaitu 24,15\%, sedangkan kadar gula total perlakuan B1G3 20,80\%. Semakin banyak penambahan buah nipah pada setiap perlakuan maka rasa manis fruit leather akan semakin meningkat. Berdasarkan analisis, kadar gula total bubur buah nipah lebih tinggi $(4,72 \%)$ dibandingkan bubur buah nanas $(2,78 \%)$.

\section{Tekstur}

Perbandingan bubur buah nipah dengan nanas terhadap tekstur fruit leather memperlihatkan pengaruh nyata $(p<0,05)$, hal ini ditunjukkan dalam hasil sidik ragam (Tabel 4). Penambahan bubur buah nipah yang semakin banyak maka cenderung semakin kenyal tekstur fruit leather, hal ini berkaitan dengan kadar air pada masing-masing bahan baku. Bubur buah nipah memiliki kadar air sebesar 90,82\%, sedangkan kadar air bubur buah nanas sebesar $84,76 \%$. Menurut Winarno (2008), penampakan dan tekstur suatu bahan pangan dipengaruhi oleh kadar air, kadar air fruit leather yang lebih rendah cenderung memberikan tekstur yang lebih keras dibandingkan berkadar air tinggi. Perlakuan B1G1 memiliki kadar air 4,34\% dengan fruit leather bertekstur kenyal, sedangkan perlakuan B1G3 yang memiliki kadar air $12,42 \%$ menghasilkan fruit leather bertekstur agak keras.

Tekstur fruit leather memperlihatkan penambahan gum arab memberikan pengaruh tidak nyata $(p>0,05)$ (Tabel 4). Walaupun gum arab berfungsi sebagai penstabil dan pengental (Suleiman, 2018), penambahan gum arab 1-1,2 \% pada penelitian ini belum mampu menghasilkan perbedaan nyata pada tekstur fruit leather yang dapat dirasakan oleh panelis. Hal ini berbeda dengan penelitian Lubis (2014), dimana penambahan gum arab terhadap tekstur fruit leather berbahan baku nanas dengan pepaya memberikan pengaruh berbeda nyata. Hal ini dikarenakan penambahan gum arab yang berbeda, yaitu $0,6 \%$ hingga $1,2 \%$ dan perbedaan bahan baku yang digunakan. Pada penelitian Lubis (2014), buah pepaya yang digunakan mengandung pektin sebesar $12 \%$, penambahan buah papaya yang semakin banyak menyebabkan pektin semakin meningkat, sehingga fruit leather semakin bertekstur tidak keras.

\section{Penilaian Keseluruhan}

Penilaian hedonik terhadap fruit leather secara keseluruhan memberikan skor rata-rata berkisar 3,164,01, dimana panelis memberikan kesan agak suka hingga suka (Tabel 4). Hasil tersebut menunjukkan bahwa fruit leather dari perbandingan bubur buah nipah dengan nanas serta penambahan gum arab dapat diterima oleh panelis berdasarkan keseluruhan parameter sensori yang dirasakan oleh panelis.

Berdasarkan Tabel 4, fruit leather perlakuan B3G2 (kombinasi $25 \%$ bubur buah nipah dengan $75 \%$ bubur buah nanas serta penambahan 1,2\% gum arab) paling disukai panelis yang memiliki skor 4,06 (suka). Fruit leather tersebut berwarna kuning (skor 4,23), beraroma buah nanas (skor 3,93), rasa manis sedikit asam (skor 3,43 ), dan tekstur agak keras (skor 3,90). Perbedaan penilaian panelis yang menyatakan suka atau tidak suka tergantung dari kesan subyektif dari panelis terhadap fruit leather. Penilaian panelis terhadap fruit leather secara keseluruhan merupakan penilaian gabungan terhadap karaktersitik warna, aroma, tekstur, serta rasa fruit leather.

\section{KESIMPULAN}

Perbandingan bubur buah nipah dengan nanas mempengaruhi kadar air, abu, serat kasar, gula total, 
total padatan terlarut, $\mathrm{pH}$, serta penilaian sensori terhadap warna, aroma, rasa, tekstur, dan keseluruhan fruit leather. Konsentrasi gum arab mempengaruhi kadar air, abu, serat kasar, total padatan terlarut, $\mathrm{pH}$, dan penilaian sensori terhadap aroma fruit leather. Interaksi antara dua faktor tersebut menunjukkan pengaruh pada nilai $\mathrm{pH}$ dan kadar serat kasar fruit leather. Perlakuan terbaik berdasarkan parameter yang dianalisis adalah B3G2 (kombinasi 25\% bubur buah nipah dengan $75 \%$ bubur buah nanas serta penambahan konsentrasi 1,2\% gum arab). Fruit leather yang dihasilkan memiliki kadar air $12,83 \%$, abu $0,79 \%$, serat kasar 2,05\%, gula total $21,21 \%$, total padatan terlarut $32,08{ }^{\circ}$ brix, $\mathrm{pH} 4,51$, dan penilaian sensori disukai panelis secara keseluruhan dengan deskripsi berwarna kuning, beraroma buah nanas, rasa manis sedikit asam, serta tekstur agak keras.

\section{KONFLIK KEPENTINGAN}

Penulis menyatakan tidak terjadi dan tidak ada konflik kepentingan diantara penulis maupun pihak lain pada penulisan artikel ilmiah ini.

\section{DAFTAR PUSTAKA}

Astuti, J., Yoza, D., \& Sulaeman, R. (2016). Potensi biomassa nipah (Nypa fruticans Wurmb.) di Desa Lubuk Muda Kecamatan Siak Kecil District Bengkalis. Jurnal Online Mahasiswa. 3(1).

Badan Standardisasi Nasional. (2008). Selai Buah SNI 3746: 2008. Jakarta.

Badan Pusat Statistik Provinsi Riau. (2016). Riau dalam Angka 2016. Pekanbaru: Badan Pusat Statistik.

Buckle, K. A., Edward, R. A., Fleet, G. H., \& Wooten, M. (2013). Ilmu Pangan. Penerjemah Hari Purnomo dan Adiono. Jakarta: Penerbit Universitas Indonesia.

Dalming, T., Aliyah, Mufidah, Margareth, V., \& Asmawati, A. (2018). Kandungan serat buah nipah (Nypa fruticans Wurmb.) dan potensinya dalam mengikat kolestrol secara in vitro. Media Farmasi. 14(1): 140-145. https:// doi.org/10.32382/mf.v14i1.149

Darojat, D. (2010). Manfaat penambahan serat pangan pada produk daging olahan. Majalah Food Riview. 5(7): 52-53.

Dhingra, D., Michae, M., Rajput, H., \& Patil, R.T. (2012). Dietary fiber in foods: a review. J Food Sci Technol. 49(3):255-266. https://doi.org/10.1007/s13197-0110365-5

Diamante, L. M., Bai, X., \& Busch, J. (2014). Fruit leathers: method of preparation and effect of different conditions on quality. International Journal of Food Science. 2014: 1-12. http://dx.doi.org/10.1155/2014/139890

Fauziah, E., Widowati, E., \& Atmaka, W. (2015). Kajian karakteristik sensorik dan fisikokimia fruit leather pisang tanduk (Musa corniculata) dengan penambahan berbagai konsentrasi karagenan. Jurnal Aplikasi Tek Pangan. 4(1).

Harahap. S. E., Karo-karo, T., \& Lubis, L.M. (2015). Pengaruh perbandingan bubur buah sirsak dengan pepaya dan penambahan gum arab terhadap mutu fruit leather. Jurnal Rekayasa Pangan dan Pertanian. 3(2).

Hassan, A., \& Othman, R. (2011). Pineapple (Ananas comosus L. Merr.). Postharvest Biology and Technology of Tropical and Subtropical Fruits. Mangosteen to White Sapote (pp. 194-217) Woodhead Publishing Series in Food Science, Technology and Nutrition.

Herman, R., Ilimu, E., Hamid, R., \& Haeruddin. (2011). Analisis kadar mineral dalam abu buah nipa (Nypa fruticans) Kaliwanggu Teluk Kendari Sulawesi Tenggara. Jurnal of Tropical Pharmacy and Chemistry. 1(2): 107-113. https://doi.org/10.25026/jtpc.v1i2.17

Lubis. M. S. P. (2014). Pengaruh Perbandingan Nanas dengan Pepaya dan Konsentrasi Gum Arab terhadap Mutu Fruit leather. Universitas Sumatera Utara.

Mahmud, M. K., Hermana, Nazarina, Marudut, Zulfianto, N. A., Muhayatun, Jahari, A. B., Permaesih. D., Ernawati. F., Rugayah, Haryono, Prihatini, S., Raswanti, I., Rahmawati, R., Santi, D., Permanasari, Y., Fahmida, U., Sulaeman, A., Andarwulan, N., Atmarita. Almasyhuri, Nurjanah, N., Ikka, N., Sianturi, G., Prihastono, \& E., Marlina, L. (2018). Tabel Komposisi Pangan Indonesia. Jakarta: Direktorat Jenderal Kesehatan Masyarakat.

Montenegro, M.A., Boiero, M.L., Valle, L., \& Borsarelli, C.D. (2012). Gum Arabic: More than an Edible Emulsifier. In: Verbeek, Dr., J. (Ed.), Products and Applications of Biopolymers. Croatia: InTech.

Nurlaely, E. (2002). Pemanfaatan Buah Jambu Mete untuk Pembuatan Leather Kajian dari Proporsi Buah Pencampur. Universitas Brawaijaya.

Prasad, N., Yang, B., Kong, K. W., Khoo, H. E., Sun, J., Azlan, A., Ismail, A., \& Romli, Z. B. (2013). Phytochemicals and antioxidant capacity from Nypa fruticans Wurmb. fruit. Evidence-Based Complementary and Alternative Medicine. 2013: 1-9. http://dx.doi.org/10.1155/2013/154606

Prasetyowati. D. A., Widowati, E., \& Nursiwi, A. (2014). Pengaruh penambahan gum arab terhadap karakteristik fisikokimia dan sensoris fruit leather nanas (Ananas comosus Merr.) dan wortel (Daucus carota). Jurnal Teknologi Pertanian. 15(2): 139-148.

Rabah \& Abdalla. (2012). Decolorization of Acacia Seyal Gum Arabic. Annual Conference of Postgraduate 
Studies and Scientific Research Hall, Khartoum. The Republic of Sudan.

Ristiyana, L. (2012). Studi Proses Pengolahan Koktail dari Tanaman Nipah (Nypa fruticans Wurmb.). Universitas Brawijaya.

Setyaningsih, D., Apriyantono, A., \& Sari, M.P. (2010). Analisis Sensori untuk Industri Pangan dan Agro. Bogor: Institut Pertanian Bogor Press.

Sulastri, T. A. (2008). Pengaruh Konsentrasi Gum Arab terhadap Mutu Velva Buah Nenas Selama Penyimpanan Dingin. Universitas Sumatera Utara.
Suliema, A. M. E. (2018). Gum Arabic as Thickener and Stabilizing Agents in Dairy Products. Gum arabic. http:// dx.doi.org/10.1016/B978-0-12-812002-6.00013-0.

Winarno, F. G. (2008). Kimia Pangan dan Gizi. Jakarta: M Brio Press.

Yebeyen, D., Lemenih, \& M. Feleke, S. (2009). Characteristics and quality of gum arabic from naturally grown Acacia senegal (Linne) Willd. trees in the Central Rift Valley of Ethiopia. Food Hydrocolloids. 23 (1):175-180. https:// doi.org/10.1016/j.foodhyd.2007.12.008 